EFFECT OF OWNERSHIP STRUCTURE AND MANAGEMENT STRUCTURE ON REAL PROFIT

MANAGEMENT PRACTICES THROUGH INFORMATION ASYMMETRY AS

INTERVENING VARIABLES

(STUDY ON COMPANIES IN THE LQ-45 INDEX 2013 - 2017)

\title{
PENGARUH STRUKTUR KEPEMILIKAN DAN STRUKTUR PENGELOLAAN TERHADAP PRAKTIK MANAJEMEN LABA RIIL MELALUI ASIMETRI INFORMASI SEBAGAI VARIABEL INTERVENING (STUDI PADA PERUSAHAAN DALAM INDEKS LQ-45 TAHUN 2013 - 2017)
}

\author{
Merry Wiraswasti $S^{1)}$, H. Mukhzarudfa ${ }^{2)}$, Tona Aurora L ${ }^{3)}$ \\ 1) Alumni Magister Ilmu Akuntansi Pascasarjana Universitas Jambi Tahun 2019 \\ ${ }^{2 \& 3)}$ Dosen Pembimbing
}

\begin{abstract}
This study aimed to provide empirical evidence of the influence of ownership structure and management structure on real earnings management practices mediated by information asymmetry. The population of this study were the LQ-45 companies that were listed on the Indonesia Stock Exchange from 2013 - 2017. The technique of sampling the study was used purposive sampling method; the sample was selected based on the suitability of the characteristics of the sample with the specified sample selection criteria. Data analysis in this study used the Partial Least Square (PLS) approach. The results of this study indicated that the ownership structure had a direct influence on information asymmetry but did not have a direct influence on real earnings management, while the management structure had a direct influence on information asymmetry and real earnings management. The results of this study also indicated that the ownership structure and management structure had an indirect influence on real earnings management mediated by information asymmetry.
\end{abstract}

Keywords: Real earnings management, ownership structure, management structure, and information asymmetry

\begin{abstract}
ABSTRAK
Penelitian ini bertujuan untuk memberikan bukti secara empiris pengaruh struktur kepemilikan dan struktur pengelolaan terhadap praktik manajemen laba riil yang dimediasi oleh asimetri informasi. Populasi penelitian ini adalah perusahaan LQ-45 yang listing dari tahun 2013 - 2017 di Bursa Efek Indonesia. Teknik penarikan sampel penelitian adalah dengan menggunakan metode purposive sampling yaitu sampel dipilih atas dasar kesesuaian karakteristik sampel dengan kriteria pemilihan sampel yang ditentukan. Analisis data dalam penelitian ini menggunakan pendekatan Partial Least Square (PLS). Hasil penelitian ini menunjukkan bahwa struktur kepemilikan memiliki pengaruh langsung terhadap asimetri informasi tetapi tidak memiliki pengaruh langsung terhadap manajemen laba riil, sedangkan struktur pengelolaan memiliki pengaruh langsung terhadap terhadap asimetri informasi dan manajemen laba riil. Hasil penelitian ini juga menunjukkan bahwa struktur kepemilikan dan struktur pengelolaan memiliki pengaruh tidak langsung terhadap manajemen laba riil yang dimediasi oleh asimetri informasi.
\end{abstract}

Kata Kunci: Manajemen laba riil, struktur kepemilikan, struktur pengelolaan, dan asimetri informasi. 


\section{PENDAHULUAN}

\subsection{Latar Belakang}

Perusahaan memiliki tujuan mendapatkan laba sebagai upaya menjaga keberlangsungan usaha. Oleh karena itu, pihak manajemen perusahaan selalu berkeinginan untuk menampilkan adanya peningkatan laba positif dalam laporan keuangan. Salah satu alternatif yang dilakukan oleh manajemen perusahaan adalah melakukan tindakan pengelolaan laba atau manajemen laba (Susanto dan Pradipta, 2016).

Manajemen laba merupakan kondisi dimana manajemen melakukan intervensi dalam proses penyusunan laporan keuangan bagi pihak eksternal. Manajemen laba dapat dikategorikan ke dalam dua hal, yaitu manajemen laba akrual dan manajemen laba riil. Hal ini berdasarkan pengaruh secara langsung atau tidaknya terhadap aliran kas. Manajemen laba akrual adalah manipulasi manajemen laba melalui estimasi dan metode akuntansi yang tidak memiliki dampak langsung terhadap aliran kas, sedangkan manajemen laba riil adalah memanipulasi laba melalui kegiatan operasional yang secara langsung mempengaruhi aliran kas (Sun et al. 2014).

Kasus manipulasi data keuangan yang banyak terjadi membuktikan bahwa masih adanya kecurangan dalam penyajian infomasi bagi pengguna laporan keuangan. Kasus manipulasi data akutansi dengan modus peningkatan laba perusahaan baru-baru ini menimpa dua perusahaan besar di dunia yaitu Toshiba dan British Telecom. Perilaku bisnis yang kurang baik ditunjukkan pada kasus skandal akuntansi di Toshiba Corp. Dilihat dari etika pada kasus ini adanya tindakan kecurangan dalam pembuatan laporan keuangan dengan menaikan laba operasional demi terciptanya kenyamanan para investor dan calon investor (Panji, 2015).

Keberadaan asimetri informasi dianggap sebagai penyebab manajemen laba. Menurut Anthony dan Govindarajan (2001) dalam Wiryadi dan Sebrina (2013) menyatakan bahwa kondisi asimetri informasi muncul dalam teori keagenan (agency theory), yaitu principal (pemilik/atasan) memberikan wewenang kepada agen (manajer/bawahan) untuk mengatur perusahaan yang dimiliki. Principal tidak memiliki informasi yang mencukupi mengenai kinerja agen, prinsipal tidak pernah tahu pasti bagaimana usaha agen memberikan kontribusi pada hasil aktual perusahaan, situasi ini disebut sebagai asimetri informasi. Semakin banyak informasi mengenai internal perusahaan yang dimiliki oleh manajer daripada pemegang saham maka manajer akan lebih banyak mempunyai kesempatan untuk melakukan manajemen laba.

Penerapan mekanisme corporate governance diharapkan dapat mengurangi dorongan manajer perusahaan untuk melakukan tindakan manipulasi, sehingga kinerja yang dilaporkan merefleksikan keadaan ekonomi yang sebenarnya dari perusahaan bersangkutan (Kusumawati, et.al., 2015). Struktur kepemilikan merupakan bagian dari tata kelola perusahaan (corporate governance) yang menjadi faktor yang mempengaruhi manajemen laba. Earnings management pada prakteknya oleh manajemen dapat diminimumkan melalui mekanisme monitoring untuk menyelaraskan (alignment) perbedaan kepentingan pemilik dan manajemen antara lain dengan; (1) memperbesar kepemilikan saham perusahaan oleh manajemen (managerial ownership); (2) kepemilikan saham oleh institusional karena mereka dianggap sebagai sophisticated investor dengan jumlah kepemilikan yang cukup signifikan dapat memonitor manajemen yang berdampak mengurangi motivasi manajer untuk melakukan earnings management (Herawaty, 2008).

Kepemilikan institusional merupakan bagian dari struktur kepemilikan yang menjadi salah satu bentuk pelaksanaan mekanisme corporate governance. Dengan kemampuannya, kepemilikan institusional dapat mengurangi insentif para manajer yang oportunis melalui pengawasan intensif. Penelitian yang dilakukan oleh Susanto dan Pradipta (2016), dan Nurlis (2016) menunjukkan bahwa kepemilikan institusional berpengaruh negatif terhadap tindakan manajemen laba riil. Hasil tersebut menunjukkan bahwa kepemilikan saham yang dimiliki institusi mampu menekan perilaku manajemen dalam melakukan aktivitas manajemen laba riil.

Kepemilikan manajerial merupakan bagian dari struktur kepemilikan perusahaan yang dianggap sebagai salah satu faktor yang berpengaruh terhadap manajemen laba yang dilakukan manajer. Kepemilikan manajerial merupakan mekanisme untuk mengurangi masalah keagenan dari manajer dengan menyelaraskan kepentingan-kepentingan manajer dengan pemegang saham. Penelitian Susanto (2016) dan Kusumawati, et.al. (2015) menyatakan bahwa kepemilikan manajerial berpengaruh positif dan signifikan terhadap manajemen laba riil.

Peningkatan tata kelola perusahaan berdasarkan mekanisme good corporate governance yaitu melalui struktur pengelolaan perusahaan yang diharapkan mampu mengurangi perilaku manajemen laba. Peningkatan tata kelola melalui struktur pengelolaan tersebut antara lain yaitu menambah proporsi dewan komisaris independen yang membatasi pihak manajemen untuk melakukan manajemen laba, menambah anggota dewan komisaris, dimana jumlah komisaris yang banyak lebih mampu mengurangi manajemen laba atau dengan adanya komite audit (Kusumawati, et.al., 2015).

Dewan komisaris independen merupakan inti dari corporate governance yang ditugaskan untuk menjamin pelaksanaan strategi perusahaan, mengawasi manajemen dalam mengelola perusahaan serta mewajibkan terlaksananya akuntabilitas (FCGI, 2000). Hasil penelitian yang dilakukan oleh Nurlis (2016), Susanto (2016), Kusumawati, et.al. (2015), Iraya, et.al. (2015) dan Uwuigbe, et.al. (2014) menunjukkan bahwa 
keberadaan komisaris independen berpengaruh negatif terhadap manajemen laba.

Komite audit mempunyai peran yang sangat penting dan strategis dalam hal memelihara kredibilitas proses penyusunan laporan keuangan seperti halnya menjaga terciptanya sistem pengawasan perusahaan yang memadai serta dilaksanakannya corporate governance (FCGI, 2000). Hasil penelitian yang dilakukan oleh Kusumawati, et.al., (2015) menyimpulkan bahwa komite audit memiliki pengaruh terhadap manajemen labariil.

Dewan direksi merupakan salah satu sistem manajemen yang memungkinkan optimalisasi peran anggota direksi dalam penyelenggaraan corporate governance. Hasil penelitian Wicaksana, et.al. (2017), Susanto dan Pradipta (2016), Susanto (2016), Iraya, et.al. (2015), Uwuigbe (2014) dan Swastika (2013) menunjukkan bahwa dewan direksi berpengaruh signifikan terhadap manajemen laba. Berdasarkan penelitian-penelitian tersebut menunjukkan bahwa dewan direksi yang ditunjukkan dengan jumlah anggota dewan direksi mampu menekan perilaku manajemen laba.

Penelitian ini merupakan pengembangan dari penelitian-penelitian sebelumnya mengenai pengaruh corporate governance terhadap manajemen laba. Peneliti tertarik melakukan penellitian mengenai pengaruh mekanisme corporate governance terhadap manajemen laba karena hasil dari penelitian-penelitian sebelumnya masih menunjukkan hasil yang beragam. Perbedaan penelitian ini dengan penelitian sebelumnya yaitu penggunaan metode analisis yang digunakan, dimana dalam penelitian ini peneliti menggunakan metode Partial Least Square (PLS) yang merupakan salah satu model dalam analisis Structure Equation Modelling (SEM), sedangkan dalam penelitian sebelumnya menggunakan metode analisis regresi. Menurut Hussein (2015) menyebutkan PLS menggunakan metode bootstraping atau penggandaan secara acak, sehingga asumsi normalitas tidak akan menjadi masalah pada saat analisis menggunakan PLS. Selain terkait normalitas data tersebut, dengan dilakukannya bootstraping maka PLS tidak mensyaratkan jumlah minimum sampel. Penelitian yang memiliki sampel kecil dapat tetap menggunakan PLS (Hussein, 2015).

Berdasarkan latar belakang tersebut, maka peneliti tertarik untuk melakukan penelitian dengan judul "Pengaruh Struktur Kepemilikan dan Struktur Pengelolaan terhadap Praktik Manajemen Laba Riil melalui Asimetri Informasi sebagai Variabel Intervening (Studi pada Perusahaan dalam Indeks LQ45 Tahun 2013 - 2017)".

\subsection{Rumusan Masalah}

Berdasarkan latar belakang yang telah dijelaskan di atas, maka rumusan masalah yang akan diteliti dalam penelitian ini adalah:
1. Apakah struktur kepemilikan berpengaruh terhadap praktik manajemen laba riil?

2. Apakah struktur pengelolaan berpengaruh terhadap praktik manajemen laba riil?

3. Apakah struktur kepemilikan berpengaruh terhadap asimetri informasi?

4. Apakah struktur pengelolaan berpengaruh terhadap asimetri informasi?

5. Apakah asimetri informasi berpengaruh terhadap praktik manajemen laba riil?

6. Apakah struktur kepemilikan berpengaruh terhadap praktik manajemen laba riil yang dimediasi oleh asimetri informasi?

7. Apakah struktur pengelolaan berpengaruh terhadap praktik manajemen laba riil yang dimediasi oleh asimetri informasi?

\subsection{Tujuan Penelitian}

Tujuan penelitian ini adalah sebagai berikut:

1. Memberikan bukti secara empiris pengaruh struktur kepemilikan terhadap praktik manajemen laba riil.

2. Memberikan bukti secara empiris pengaruh struktur pengelolaan terhadap praktik manajemen laba riil.

3. Memberikan bukti secara empiris pengaruh struktur kepemilikan terhadap asimetri informasi.

4. Memberikan bukti secara empiris pengaruh struktur pengelolaan terhadap asimetri informasi.

5. Memberikan bukti secara empiris pengaruh asimetri informasi terhadap praktik manajemen laba riil.

6. Memberikan bukti secara empiris pengaruh struktur kepemilikan secara tidak langsung terhadap praktik manajemen laba riil yang dimediasi oleh asimetri informasi.

7. Memberikan bukti secara empiris pengaruh struktur pengelolaan secara tidak langsung terhadap praktik manajemen laba riil yang dimediasi oleh asimetri informasi.

\section{TINJAUAN PUSTAKA}

\subsection{Struktur Kepemilikan}

Sugiarto (2009) menyatakan bahwa struktur kepemilikan adalah struktur kepemilikan saham yaitu perbandingan jumlah saham yang dimiliki oleh orang dalam (insider) dengan jumlah saham yang dimiliki oleh investor. Atau dengan kata lain struktur kepemilikan saham adalah proporsi kepemilikan institusional dan kepemilikan manajemen dalam kepemilikan saham perusahaan. Suatu perusahaan dalam menjalankan kegiatannya diwakili oleh direksi (agents) yang ditunjuk oleh pemegang saham (principals). 
Dalam penelitian ini mencakup 2 kategori yaitu kepemilikan institusional dan kepemilikan manajerial.

1. Kepemilikan Institusional

Menurut Yang et al. (2009) menyebutkan bahwa kepemilikan institusional adalah proporsi saham yang dimiliki oleh investor institusi, seperti perusahaan asuransi, institusi keuangan (bank, perusahaan keuangan, kredit), dana pensiun, investment banking, dan perusahaan lainnya yang terkait dengan kategori tersebut. Kepemilikan institusional memiliki arti penting dalam memonitor kinerja manajemen, karena dengan adanya kepemilikan oleh institusional akan mendorong peningkatan pengawasan yang lebih optimal. Monitoring yang dilaksanakan oleh institusi akan menjamin kepentingan pemegang saham sehingga pengaruh kepemilikan institusional sebagai agen pengawas ditentukan melalui investasi mereka yang cukup besar dalam pasar modal.

\section{Kepemilikan Manajerial}

Kepemilikan manajerial merupakan proporsi saham yang dimiliki oleh manajemen perusahaan. Pengukuran kepemilikan manajerial dengan menghitung persentase saham yang dimiliki oleh manajemen perusahaan dengan seluruh jumlah saham perusahaan yang beredar. Kepemilikan manajerial merupakan salah satu mekanisme corporate governance yang dapat digunakan untuk mengurangi agency cost. Jensen dan Meckling (1976), menyatakan bahwa kepemilikan saham perusahaan oleh manajemen dapat menyetarakan kepentingan pemegang saham dengan kepentingan manajer sehingga konflik kepentingan antara pemegang saham dan manajer dapat dikurangi.

\subsection{Struktur Pengelolaan}

Penerapan prinsip Corporate Governance adalah untuk menghasilkan kinerja perusahaan yang efektif dan efisien melalui struktur pengelolaan. KNKG (2006) menyatakan bahwa organ perusahaan yang tersusun dalam struktur pengelolaan perusahaan terdiri dari Rapat Umum Pemegang Saham (RUPS), Dewan Komisaris, Direksi dan Komite Audit, mempunyai peran penting dalam pelaksanaan GCG secara efektif. Organ-organ perusahaan tersebut menjalankan fungsinya secara independen atas dasar prinsip bahwa masing-masing organ mempunyai independensi dalam melaksanakan tugas, fungsi dan tanggung jawabnya semata-mata untuk kepentingan perusahaan.

Organ perusahaan dalam rangka penyelenggaraan corporate governance yang baik yang dimaksudkan oleh KNKG (2006), antara lain:

\section{Rapat Umum Pemegang Saham (RUPS)}

Menurut KNKG (2006), RUPS sebagai sebuah organ perusahaan merupakan wadah para pemegang saham untuk mengambil keputusan penting yang berkaitan dengan modal yang ditanam dalam perusahaan, dengan memperhatikan ketentuan anggaran dasar dan peraturan perundang-undangan.

2. Dewan Komisaris

Dewan Komisaris merupakan organ perusahaan yang memiliki tugas dan tanggung jawab untuk melakukan pengawasan dan memberikan nasihat kepada direksi serta memastikan bahwa perusahaan melaksanakan corporate governance.

\section{Direksi}

Direksi merupakan organ perusahaan yang memiliki tugas dan tanggung jawab dalam mengelola perusahaan. Anggota dewan direksi melaksanakan tugas dan mengambil keputusan sesuai dengan pembagian tugas dan wewenangnya masing-masing. Pelaksanaan tugas anggota direksi tetap merupakan tanggung jawab bersama secara kolektif semua anggota direksi. Kedudukan setiap anggota dewan direksi adalah setara termasuk direktur utama. Tugas direktur utama adalah sebagai Primus Inter Pares yaitu mengkoordinasikan kegiatan direksi (KNKG, 2006).

\section{Komisaris Independen}

Menurut KNKG (2006), dewan komisaris dapat terdiri dari komisaris komisaris independen yaitu komisaris yang tidak berasal dari pihak terafiliasi dan komisaris yang terafiliasi dengan perusahaan. Bagi perusahaan yang listed di Bursa harus memiliki komisaris independen yang secara proporsional sama dengan jumlah saham yang dimiliki pemegang saham minoritas (bukan controlling shareholders). Peraturan ini mempersyaratkan jumlah minimal komisaris independen adalah $30 \%$ dari seluruh anggota dewan komisaris.

\section{Komite Audit}

Dewan komisaris membentuk komite-komite untuk membantu pelaksanaan tugasnya. Komite audit merupakan salah satu komite yang dibentuk oleh dewan komisaris untuk membantu pelaksanaan tugas dewan komisaris dalam melakukan pengawasan terhadap kinerja perusahaan. Forum Corporate Governance in Indonesia (FCGI) (2000), menyatakan bahwa komite audit memiliki tugas terpisah dalam membantu dewan komisaris untuk memenuhi tanggung jawabnya dalam memberikan pengawasan secara menyeluruh.

\subsection{Asimetri Informasi}

Teori agensi yang dikemukakan oleh Jensen dan Meckling (1976) telah diungkapkan bahwa dalam dunia bisnis terjadi fenomena oportunis dan manusia sebagai individu cenderung untuk memenuhi utilitasnya secara maksimal. Hal ini mengakibatkan adanya distribusi informasi yang tidak merata antara agent dan principal. Distribusi informasi yang tidak meratajuga disebut sebagai asimetri informasi. Asimetri informasi adalah suatu keadaan dimana agent mempunyai informasi tentang perusahaan lebih banyak daripada principal. 
Agent disini dapat juga mengetahui prospek tentang perusahaan di masa depan. Kondisi ketimpangan informasi ini juga dapat memberikan peluang kepada agent untuk memanipulasi pelaporan untuk memaksimalkan utilitasnya (Pratiwi et.al., (2015).

Asimetri informasi diukur dengan menggunakan Relative Bid-ask Spread. Dimana asimetri informasi dilihat dari selisih harga saat ask dengan harga bid saham perusahaan atau selisih harga jual dan harga beli saham perusahaan selama satu tahun. Relative bid-ask spread bisa menggambarkan terjadinya perbedaan informasi yang tinggi antara principal dan agent, dengan melihat perbedaan harga antara bid dan ask maka bisa menggambarkan manajemen laba yang terjadi dalam perusahaan. Jika spread yang terjadi dalam perusahaan tinggi maka kemungkinan manajemen laba yang terjadi dalam tubuh perusahaan semakin tinggi. Namun jika spread yang terjadi rendah maka bisa menggambarkan manajemen laba yang terjadi dalam perusahaan rendah (Wiryandi dan Sebrina, 2013).

\subsection{Manajemen Laba Riil (Real Earnings Management)}

Healy dan Wahlen (1999) dalam Herawaty (2008), menyatakan bahwa manajemen laba terjadi ketika manajemen menggunakan judgment dalam pelaporan keuangan yang dapat merubah laporan keuangan sehingga menyesatkan pihak-pihak yang berkepentingan dengan perusahaan. Ada berbagai motivasi yang diduga mendasari dan mendorong seorang manajer berprilaku oportunitis. Motivasimotivasi tersebut akan mempengaruhi pola rekayasa manajerial yang dilakukan manajemen perusahaan.

Manajemen laba dapat dikategorikan menjadi manajamen laba akrual (accrual earnings management) dan manajemen laba riil (real earnings management). Manajemen laba akrual adalah manipulasi manajemen laba melalui estimasi dan metode akuntansi yang tidak memiliki dampak langsung terhadap arus kas. Sebaliknya, manajemen laba riil adalah memanipulasi laba melalui kegiatan operasional yang secara langsung mempengaruhi arus kas (Sun et al. 2014). Manajemen laba riil dapat dilakukan sepanjang periode akuntansi dengan beberapa tujuan yaitu, mencapai target laba tertentu, menghindari kerugian, dan mencapai target analyst forecast.

Pendeteksian tindakan manajemen laba riil melalui manipulasi aktivitas riil yang dilakukan oleh perusahaan, Sun et al. (2014) menggunakan model yang dikembangkan oleh Roychowdhury (2006) dan fokus pada tiga pendekatan manipulasi berikut :

\section{Manipulasi penjualan (sales manipulation)}

Merupakan usaha untuk meningkatkan penjualan secara temporer dalam periode tertentu dengan menawarkan diskon harga produk secara berlebihan atau memberikan persyaratan kredit yang lebih lunak.
2. Penurunan beban-beban diskresioner (dicretionary expenditures)

Tindakan manajemen riil yang dilakukan perusahaan dengan menurunkan discretionary expenditures seperti beban penelitian dan pengembangan, iklan, dan penjualan, adminstrasi, dan umum. Contoh dari praktik manajemen laba riil dengan menurunkan beban-beban diskresioner ini yaitu dengan dengan pengurangan beban diskresioner dalam bentuk kas, sehingga pengurangan beban diskresioner tersebut akan memperkecil arus kas keluar.

\section{Produksi yang berlebihan (over production)}

Metode produksi yang berlebihan merupakan tindakan manajemen laba riil yang dilakukan perusahaan untuk meningkatkan laba, dimana manajer perusahaan memproduksi lebih banyak daripada yang diperlukan namun biaya produksi tetap (fixed cost) sehingga biaya per unit produk lebih rendah. Strategi ini dapat menurunkan harga pokok penjualan (cost of goods sold) dan meningkatkan laba operasi.

\section{METODOLOGI PENELITIAN}

\subsection{Objek Penelitian}

Penelitian ini merupakan penelitian kuantitatif bersifat hubungan causal explanatory yang bertujuan mengetahui pola hubungan kausal antara variabel independen dan variabel dependen. Penggunaan metode causal explanatory sesuai dengan tujuan penelitian yaitu melakukan pengujian hipotesa yang menguji hubungan dan pengaruh diantara variabel yang diteliti. Pemilihan jenis penelitian ini sesuai dengan tujuan penelitian, yaitu untuk mengetahui apakah struktur kepemilikan dan struktur pengelolaan berpengaruh terhadap manajemen laba riil.

Objek yang diteliti dalam penelitian ini adalah variabel yang terkait dalam penelitian yaitu manajemen laba riil yang merupakan variabel dependen, sedangkan struktur kepemilikan, struktur pengelolaan, dan asimetri informasi merupakan variabel independen. Subjek Penelitian ini adalah perusahaan yang terdaftar pada LQ-45 di BEI periode 2013 - 2017.

\subsection{Populasi dan Sampel}

Populasi penelitian ini adalah perusahaan LQ-45 yang listing dari tahun 2013 - 2017 di Bursa Efek Indonesia. Teknik penarikan sampel penelitian adalah dengan menggunakan metode purposive sampling yaitu sampel dipilih atas dasar kesesuaian karakteristik sampel dengan kriteria pemilihan sampel yang ditentukan.

Proses purposive sampling dalam penelitian dapat dilihat pada tabel berikut ini : 
Tabel 1.

Proses Purposive Sampling Penelitian

\begin{tabular}{|c|l|c|}
\hline No & \multicolumn{1}{|c|}{ Purposive Sampling } & Jumlah \\
\hline 1 & Perusahaan LQ-45 di BEI & $(45)$ \\
\hline 2 & $\begin{array}{l}\text { Dikurangi Perusahaan yang tidak konsisten bergabung di LQ-45 berturut-turut selama } \\
\text { periode 2013 - 2017. }\end{array}$ & $(21)$ \\
\hline 3 & Perusahaan yang bergerak dalam bidang keuangan (perbankan) & $(4)$ \\
\hline 4 & Perusahaan menggunakan mata uang dollar dalam laporan keuangan & $(2)$ \\
\hline \multicolumn{1}{|}{ Jumlah } & $(18)$ \\
\hline
\end{tabular}

\subsection{Analisis Data}

Analisis data dalam penelitian ini dilakukan dengan metode Structural Equation Modelling (SEM) dengan menggunakan Partial Least Square (PLS) dibantu dengan software smartPLS 3.0. Keuntungan dengan menggunakan PLS adalah PLS merupakan metode analisis yang powerfull oleh karena tidak mengasumsikan data harus dengan skala tertentu dan jumlah sampel kecil (Ghozali, 2011). Langkah-langkah analisis menggunakan Structural Equation Modelling yaitu sebagai berikut:

\subsubsection{Uji Kualitas Data/Measurement Model}

Uji kualitas data atau pengukuran model (measurement model) dimaksudkan untuk mengetahui seberapa besar tingkat konsistensi dan akurasi data yang dikumpulkan dari penggunaan instrumen penelitian. Outer Model merupakan model pengukuran untuk menilai validitas parameter model pengukuran (validitas konvergen, validitas diskriminan, composite reliability dan cronbach's alpha) termasuk nilai $\mathrm{R}^{2}$ sebagai parameter ketepatan model prediksi (Hengky dan Ghazali, 2012).

\section{a. Uji Reliabilitas}

Uji reliabilitas dalam PLS dapat menggunakan dua metode, yaitu Cronbach's alpha dan Composite reliability. Cronbach'alpha mengukur batas bawah nilai reliabilitas suatu konstruk sedangkan composite reliability mengukur nilai sesungguhnya reliabilitas suatu konstruk. Suatu konstruk dikatakan reliabel jika nilai Cronbach's alpha harus lebih dari 0,6 dan nilai composite reliability harus lebih dari 0,7 (Hengky dan Ghazali, 2012). b. Uji Validitas

Pengujian validitas menggunakan Partial Least Square (PLS) dapat dilihat dari pengujian validitas convergent dan discriminant. Validitas convergent dihitung dengan melihat skor Average Variance Extracted (AVE). Nilai validitas convergent dikatakan sangat baik apabila skor AVE di atas 0,5 (Hussein, 2015).

\subsubsection{Pengujian Hipotesis}

Untuk pengujian hipotesis atas pengaruh struktur kepemilikan dan struktur pengelolaan terhadap manajemen laba riil dilakukan dengan melakukan perbandingan antara hasil path coeffecient dengan $t_{\text {tabel }}$. Hipotesis dapat dikatakan sangat signifikan apabila $t_{\text {hitung }}>t_{\text {tabel }}$ dan nilai p-value lebih kecil dari taraf signifikansi $\alpha=0,05$.

\section{HASIL DAN PEMBAHASAN}

\subsection{Hasil Penelitian}

\subsubsection{Pengujian Outer Model}

Analisis ini dilakukan dengan melihat validitas dan reliabilitas dari indikator yang digunakan dalam mengukur variabel laten yang terdiri dari struktur kepemilikan, struktur pengelolaan, asimetri informasi, dan manajemen laba riil.

a. Uji Validitas

Pengujian validitas konvergen dilakukan menggunakan nilai loading faktor. Hasil outer loading dapat dilihat pada tabel berikut ini:

Tabel 2.

Nilai Loading Factor pada Indikator untuk Masing-masing Variabel Laten

\begin{tabular}{|l|c|c|c|c|}
\hline & $\begin{array}{c}\text { Struktur } \\
\text { Kepemilikan }\end{array}$ & $\begin{array}{c}\text { Struktur } \\
\text { Pengelolaan }\end{array}$ & $\begin{array}{c}\text { Asimetri } \\
\text { Informasi }\end{array}$ & $\begin{array}{c}\text { Manajemen } \\
\text { Laba Riil }\end{array}$ \\
\hline Institusi & 0.880 & & & \\
\hline Manager & -0.429 & & & \\
\hline Independen & & 0.667 & & \\
\hline
\end{tabular}




\begin{tabular}{|l|l|l|l|l|}
\hline Audit & & 0.922 & & \\
\hline Direksi & & 0.617 & & \\
\hline Spread & & & 1.000 & \\
\hline ACFO & & & & 1.000 \\
\hline
\end{tabular}

Sumber: Data primer diolah, 2019

Berdasarkan tabel di atas dapat dilihat nilai loading factor untuk indikator kepemilikan manajerial sebesar -0,429 lebih kecil dari 0,5 yang berarti bahwa kedua indikator tersebut tidak valid dan tidak bisa dipergunakan untuk mengukur variabel laten struktur kepemilikan. Sementara itu, indikator kepemilikan institusional sebesar 0,880 lebih besar dari 0,5 yang berarti indikator tersebut valid dan mampu mengukur variabel struktur kepemilikan. Oleh karena itu, indikator kepemilikan manajerial tidak dipergunakan dalam tahap analisis selanjutnya sehingga pengukuran struktur kepemilikan hanya menggunakan indikator kepemilikan institusional.
Nilai loading factor untuk masing-masing indikator dalam variabel laten struktur pengelolaan dengan nilai loading factor lebih besar dari 0,5 yang berarti bahwa semua indikator dinyatakan valid dan dapat dipergunakan sebagai indikator untuk mengukur variabel laten struktur kepemilikan. Variabel laten asimetri informasi dan manajemen laba riil diukur hanya menggunakan satu indikator sehingga nilai loading factor-nya sama dengan 1.

Hasil pengujian cross loading dapat dilihat pada tabel berikut:

Tabel 3.

Cross Loading Setiap Indikator dengan Variabel Latennya

\begin{tabular}{|l|c|c|c|c|}
\hline & $\begin{array}{c}\text { Struktur } \\
\text { Kepemilikan }\end{array}$ & $\begin{array}{c}\text { Struktur } \\
\text { Pengelolaan }\end{array}$ & $\begin{array}{c}\text { Asimetri } \\
\text { Informasi }\end{array}$ & $\begin{array}{c}\text { Manajemen } \\
\text { Laba Riil }\end{array}$ \\
\hline Institusi & $\mathbf{0 . 8 8 0}$ & 0.103 & 0.403 & 0.052 \\
\hline Manager & $\mathbf{- 0 . 4 2 9}$ & 0.149 & -0.166 & -0.179 \\
\hline Independen & 0.021 & $\mathbf{0 . 6 6 7}$ & 0.269 & 0.222 \\
\hline Audit & -0.011 & $\mathbf{0 . 9 2 2}$ & 0.492 & 0.468 \\
\hline Direksi & 0.095 & $\mathbf{0 . 6 1 7}$ & 0.284 & 0.024 \\
\hline Spread & 0.444 & 0.493 & $\mathbf{1 . 0 0 0}$ & 0.493 \\
\hline ACFO & 0.133 & 0.399 & 0.493 & $\mathbf{1 . 0 0 0}$ \\
\hline
\end{tabular}

Sumber: Data primer diolah, 2019

Berdasarkan tabel di atas dapat dilihat bahwa pada indikator kepemilikan manajerial, nilai loading factor dengan variabel latennya (struktur kepemilikan) lebih rendah dari nilai loading factor dengan variabel yang lain. Sementara itu nilai loading factor untuk indikator kepemilikan institusional dengan variabel laten struktur kepemilikan lebih besar daripada nilai loading factor dengan variabel laten yang lain. Begitupun nilai loading factor indikator proporsi komisaris independen, komite audit, dan dewan direksi nilai loading factor dengan variabel laten struktur pengelolaan lebih besar daripada nilai loading factor dengan variabel laten yang lain. Nilai loading factor spread untuk mengukur variabel laten asimetri informasi, dan abnormal cash flow operation (ACFO) untuk mengukur variabel laten manajemen laba riil masing-masing bernilai 1 lebih besar dari nilai loading factor terhadap variabel laten yang lain.

Pengukuran validitas discriminant dihitung dengan melihat skor Average Variance Extracted (AVE). Hasil pengukuran dapat dilihat pada tabel berikut ini:

Tabel 4.

Hasil Pengukuran Average Variance Extracted

\begin{tabular}{|l|r|}
\hline \multicolumn{1}{|c|}{ Variabel Laten } & Average Variance Extracted $(\boldsymbol{A V E})$ \\
\hline Struktur Kepemilikan & 0.479 \\
\hline Struktur Pengelolaan & 0.559 \\
\hline Asimetri Informasi & 1.000 \\
\hline Manajemen Laba Riil & 1.000 \\
\hline
\end{tabular}

Sumber: Data primer diolah, 2019 
Berdasarkan tabel di atas dapat dilihat bahwa nilai AVE untuk variabel laten struktur kepemilikan sebesar 0,479 lebih kecil dari 0,5 sehingga indikator yang digunakan (kepemilikan institusional dan kepemilikan manajerial) tidak mampu mengukur variabel struktur kepemilikan dengan baik. Setelah indikator kepemilikan manajerial tidak dipergunakan, maka pengukuran struktur kepemilikan hanya menggunakan satu indikator sehingga nilai AVE menjadi sama dengan 1,000.

Nilai AVE pada variabel laten struktur pengelolaan sebesar 0,559 lebih besar dari 0,5 sehingga semua indikator yang digunakan untuk mengukur variabel laten struktur pengelolaan memenuhi validitas diskriminan dan bisa dipergunakan dalam proses tahap analisis selanjutnya. Sementara itu nilai AVE pada variabel laten asimetri informasi, dan manajemen laba riil sebesar 1,000 yang berarti bahwa semua indikator pada masing-masing variabel laten mampu mampu mengukur dengan baik variabel latennya.

b. Uji Reliabilitas

Uji reliabilitas dilakukan dengan melihat nilai composite reliability dan cronbach alpha yang tinggi. Nilai yang disarankan untuk nilai composite reliability jika lebih besar dari 0,7 dan nilai cronbach alpha lebih besar dari 0,6. Nilai composite reliability dan cronbach alpha dapat dilihat pada tabel berikut:

Tabel 5.

Nilai Composite Reliability

\begin{tabular}{|l|c|c|}
\hline \multicolumn{1}{|c|}{ Variabel Laten } & Cronbach's Alpha & $\begin{array}{c}\text { Composite } \\
\text { Reliability }\end{array}$ \\
\hline Struktur Kepemilikan & 0.099 & 0.163 \\
\hline Struktur Pengelolaan & 0.624 & 0.786 \\
\hline Asimetri Informasi & 1.000 & 1.000 \\
\hline Manajemen Laba Riil & 1.000 & 1.000 \\
\hline
\end{tabular}

Sumber: Data primer diolah, 2019

Berdasarkan tabel di atas dapat dilihat bahwa nilai composite reliability untuk variabel struktur kepemilikan sebesar 0,163 lebih kecil dari 0,7. Hal ini berarti bahwa hasil pengukuran pada setiap konstruk tidak reliabel dan tidak mampu menjelaskan dengan baik variabel struktur kepemilikan. Nilai cronbach alpha pada variabel laten struktur kepemilikan sebesar 0,099 lebih kecil dari 0,6 yang berarti bahwa konstruk untuk mengukur struktur kepemilikan tidak reliabel dan indikator untuk mengukur variabel laten kurang dapat diandalkan. Setelah indikator kepemilikan manajerial tidak digunakan, maka struktur kepemilikan hanya diukur menggunakan satu indikator sehingga nilai composite reliability dan cronbach alpha menjadi sama dengan 1,000 dan hasil pengukuran menjadi reliabel dan mampu menjelaskan dengan baik variabel struktur kepemilikan.

Nilai composite reliability untuk variabel struktur pengelolaan sebesar 0,786 lebih besar dari 0,7 . Hal ini berarti bahwa hasil pengukuran pada setiap konstruk reliabel dan mampu menjelaskan dengan baik variabel struktur pengelolaan. Nilai cronbach alpha pada variabel laten struktur pengelolaan sebesar 0,624 lebih besar dari 0,6 yang berarti bahwa konstruk untuk mengukur struktur pengelolaan reliabel dan data hasil pengukuran semua indikator untuk mengukur variabel laten dapat diandalkan.

Nilai composite reliability untuk variabel asimetri informasi dan manajemen laba riil sebesar 1,000 lebih besar dari 0,7. Hal ini berarti bahwa hasil pengukuran pada setiap konstruk reliabel dan mampu menjelaskan dengan baik variabel variabel asimetri informasi dan manajemen laba riil. Nilai cronbach alpha pada masing-masing variabel laten asimetri informasi dan manajemen laba riil sebesar 1,000 lebih besar dari 0,6 yang berarti bahwa konstruk untuk mengukur kedua variabel laten tersebut reliabel dan data hasil pengukuran semua indikator untuk mengukur variabel laten dapat diandalkan.

\subsubsection{Pengujian Inner Model}

Penelitian ini dilakukan untuk melihat pengaruh struktur kepemilikan dan struktur pengelolaan terhadap manajemen laba riil yang dimediasi oleh asimetri informasi. Analisis data dilakukan dengan melihat pengaruh dari varibel struktur kepemilikan dan struktur pengelolaan secara langsung terhadap manajemen laba riil dan secara tidak langsung dengan dimediasi oleh asimetri informasi. 
Tabel 6.

Hasil Pengujian Pengaruh Langsung

\begin{tabular}{|l|r|r|r|}
\hline & Koefisien Path & T Statistics & \multicolumn{1}{|c|}{$\boldsymbol{P}$ Values } \\
\hline Struktur Kepemilikan -> Asimetri Informasi & 0.356 & 4.939 & 0.000 \\
\hline Struktur Kepemilikan -> Manajemen Laba Riil & -0.153 & 1.763 & 0.078 \\
\hline Struktur Pengelolaan -> Asimetri Informasi & 0.456 & 4.931 & 0.000 \\
\hline Struktur Pengelolaan -> Manajemen Laba Riil & 0.186 & 2.077 & 0.038 \\
\hline Asimetri Informasi -> Manajemen Laba Riil & 0.463 & 5.444 & 0.000 \\
\hline
\end{tabular}

Pengujian hipotesis dilakukan untuk menguji signifikansi hubungan antar variabel laten penelitian. Kriteria yang digunakan yaitu dengan membandingkan nilai $p$-value hasil pengujian hipotesis dengan taraf signifikansi 0,05 . Jika $p$-value $\leq 0,05$, maka hipotesis statistik diterima dengan demikian variabel eksogen berarti memiliki pengaruh langsung yang signifikan terhadap variabel endogennya. Hasil pengujian hipoteis pengaruh langsung dapat dilihat pada Tabel 6 . Berdasarkan Tabel 6 dapat dirumuskan hasil pengujian hipotesis sebagai berikut:

a. Pengaruh struktur kepemilikan terhadap asimetri informasi dengan nilai $p$-value sebesar 0,000 lebih kecil dari taraf signifikansi 0,05. Hal ini berarti $\mathrm{H} 0$ ditolak dan Ha diterima. Dengan demikian struktur kepemilikan memiliki pengaruh langsung yang signifikan terhadap asimetri informasi.

b. Pengaruh struktur kepemilikan terhadap manajemen laba riil dengan nilai $p$-value sebesar 0,078 lebih besar dari taraf signifikansi 0,05 . Hal ini berarti H0 diterima dan Ha ditolak. Dengan demikian struktur kepemilikan tidak memiliki pengaruh langsung yang signifikan terhadap manajemen laba riil.

c. Pengaruh struktur pengelolaan terhadap asimetri informasi dengan nilai p-value sebesar 0,000 lebih kecil dari taraf signifikansi 0,05. Hal ini berarti H0 ditolak dan Ha diterima. Dengan demikian struktur pengelolaan memiliki pengaruh langsung yang signifikan terhadapasimetri informasi.

d. Pengaruh struktur pengelolaan terhadap manajemen laba riil dengan nilai $p$-value sebesar 0,038 lebih kecil dari taraf signifikansi 0,05. Hal ini berarti H0 ditolak dan Ha diterima. Dengan demikian struktur pengelolaan memiliki pengaruh langsung yang signifikan terhadap manajemen laba riil.

e. Pengaruh asimetri informasi terhadap manajemen laba riil dengan nilai $p$-value sebesar 0,000 lebih kecil dari taraf signifikansi 0,05. Hal ini berarti H0 ditolak dan Ha diterima. Dengan demikian asimetri informasi memiliki pengaruh langsung yang signifikan terhadap manajemen laba riil.

Pengujian pengaruh tidak langsung struktur kepemilikan dan struktur pengelolaan terhadap manajemen laba riil yang dimediasi oleh asimetri informasi dapat dilihat pada tabel berikut ini:

Tabel 7.

Hasil Pengujian Pengaruh Tidak Langsung

\begin{tabular}{|l|c|c|r|}
\hline & Koefisien Path & T Statistics & P Values \\
\hline $\begin{array}{l}\text { Struktur Kepemilikan -> Asimetri Informasi -> } \\
\text { Manajemen Laba Riil }\end{array}$ & 0,165 & 4.057 & 0.000 \\
\hline $\begin{array}{l}\text { Struktur Pengelolaan -> Asimetri Informasi -> } \\
\text { Manajemen Laba Riil }\end{array}$ & 0,211 & 3.068 & 0.002 \\
\hline
\end{tabular}

Sumber: Data primer diolah, 2019

Hasil pengujian hipotesis pengaruh tidak langsung struktur kepemilikan dan struktur pengelolaan terhadap manajemen laba riil yang dimediasi oleh asimetri informasi dapat dilihat pada tabel 7. Hasil pengujian hipotesis tidak langsung yaitu sebagai berikut:

a. Pengaruh tidak langsung struktur kepemilikan terhadap manajemen laba riil yang dimediasi oleh asimetri informasi dengan nilai $p$-value sebesar 0,000 lebih kecil dari taraf signifikansi 0,05 . Hal ini berarti $\mathrm{H}_{0}$ ditolak dan Ha diterima. Dengan demikian struktur kepemilikan memiliki pengaruh tidak langsung yang signifikan terhadap manajemen laba riil yang dimediasi oleh asimetri informasi.

b. Pengaruh tidak langsung struktur pengelolaan terhadap manajemen laba riilyang dimediasi oleh asimetri informasi dengan nilai $p$-value sebesar 0,002 lebih kecil dari taraf signifikansi 0,05 . Hal ini berarti $\mathrm{H}_{0}$ ditolak dan Ha diterima. Dengan demikian 
struktur kepemilikan memiliki pengaruh tidak langsung yang signifikan terhadap manajemen laba riilyang dimediasi oleh asimetri informasi.
Secara keseluruhan hasil analisis data dapat digambarkan sebagai berikut:

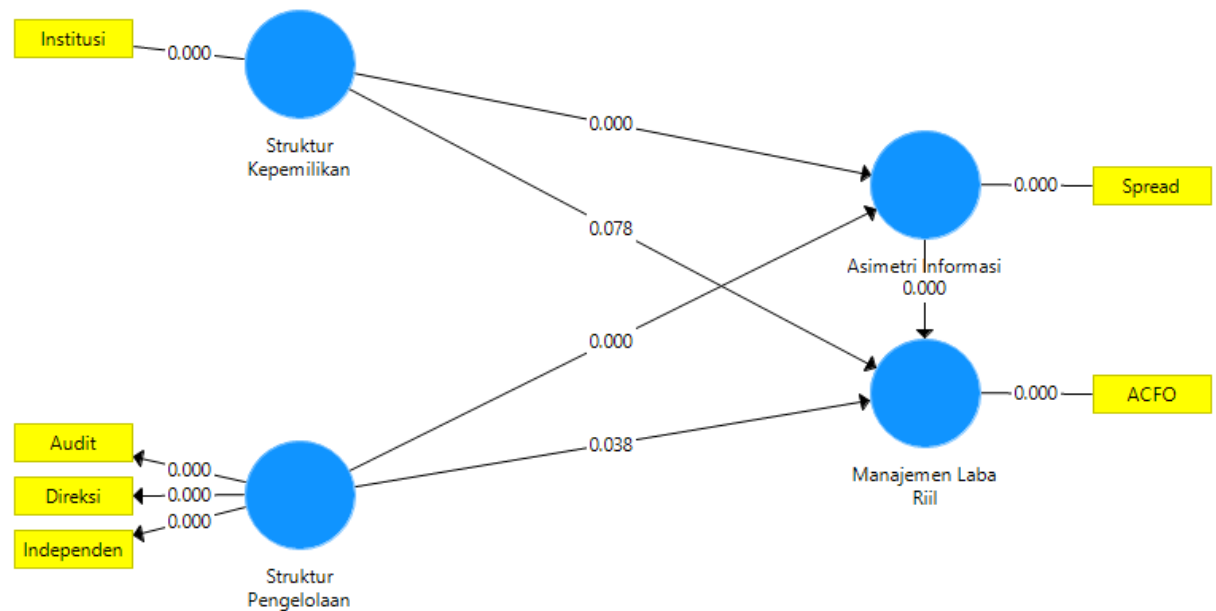

Gambar 1.

Hasil Pengujian Model

\subsection{Pembahasan}

\subsubsection{Pengaruh Langsung Struktur Kepemilikan terhadap Asimetri Informasi pada Perusahaan Yang Terdaftar dalam Indeks LQ-45 di BEI Tahun 2013 - 2017}

Hasil penelitian menunjukkan adanya pengaruh langsung yang signifikan dari struktur kepemilikan terhadap asimetri informasi. Hal ini terbukti melalui hasil pengujian hipotesis dalam persamaan analisis jalur yang menunjukkan bahwa nilai probabilitas koefisien path pengaruh struktur kepemilikan terhadap asimetri informasi sebesar 0,000 lebih kecil dari taraf signifikansi 0,05. Besarnya pengaruh struktur kepemilikan terhadap asimetri informasi yaitu sebesar $35,6 \%$. Dengan demikian, peningkatan asimetri informasi perusahaan yang terdaftar dalam indeks LQ45 di BEI Tahun 2013 - 2017 sangat dipengaruhi oleh adanya peningkatan struktur kepemilikan dengan kemampuan menjelaskan sebesar 35,6\%. Semakin besar struktur kepemilikan institusional, maka semakin tinggi pula asimetri informasi perusahaan yang terdaftar dalam indeks LQ-45 di BEI Tahun 2013 - 2017.

\subsubsection{Pengaruh Langsung Struktur Pengelolaan terhadap Asimetri Informasi pada Perusahaan Yang Terdaftar dalam Indeks LQ-45 di BEI Tahun 2013 - 2017}

Hasil penelitian menunjukkan adanya pengaruh langsung yang signifikan dari struktur pengelolaan terhadap asimetri informasi. Hal ini terbukti melalui hasil pengujian hipotesis dalam persamaan analisis jalur yang menunjukkan bahwa nilai probabilitas koefisien path pengaruh struktur pengelolaan terhadap asimetri informasi sebesar 0,000 lebih kecil dari taraf signifikansi 0,05. Besarnya pengaruh struktur pengelolaan terhadap asimetri informasi yaitu sebesar 45,6\%. Dengan demikian, peningkatan asimetri informasi perusahaan yang terdaftar dalam indeks LQ45 di BEI Tahun 2013 - 2017 sangat dipengaruhi oleh adanya peningkatan struktur pengelolaan dengan kemampuan menjelaskan sebesar 45,6\%. Semakin besar struktur pengelolaan maka semakin tinggi pula asimetri informasi perusahaan yang terdaftar dalam indeks LQ45 di BEI Tahun 2013 - 2017.

\subsubsection{Pengaruh Langsung Struktur Kepemilikan terhadap Manajemen Laba Riil pada Perusahaan Yang Terdaftar dalam Indeks LQ-45 di BEI Tahun 2013 - 2017}

Hasil penelitian menunjukkan tidak adanya pengaruh langsung yang signifikan dari struktur kepemilikan terhadap manajemen laba riil pada perusahaan yang terdaftar dalam indeks LQ-45 di BEI Tahun 2013 2017. Hal ini terbukti melalui hasil pengujian hipotesis dalam persamaan analisis jalur yang menunjukkan bahwa nilai probabilitas koefisien path pengaruh struktur kepemilikan terhadap manajemen laba riil yaitu sebesar 0,078 lebih besar dari taraf signifikansi 0,05. Besarnya pengaruh struktur kepemilikan hanya sebesar $15,3 \%$ sehingga tidak mampu memberikan kontribusi yang signifikan terhadap penurunan manajemen laba riil pada perusahaan yang terdaftar dalam indeks LQ-45 di BEI Tahun 2013 - 2017. 


\subsubsection{Pengaruh Langsung Struktur Pengelolaan terhadap Manajemen Laba Riil pada Perusahaan Yang Terdaftar dalam Indeks LQ-45 di BEI Tahun 2013 - 2017}

Hasil penelitian menunjukkan adanya pengaruh langsung yang signifikan dari struktur pengelolaan terhadap manajemen laba riil pada perusahaan yang terdaftar dalam indeks LQ-45 di BEI Tahun 2013 2017. Hal ini terbukti melalui hasil pengujian hipotesis dalam persamaan analisis jalur yang menunjukkan bahwa nilai probabilitas koefisien path pengaruh struktur pengelolaan terhadap manajemen laba riil yaitu sebesar 0,038 lebih kecil dari taraf signifikansi 0,05. Besarnya pengaruh struktur pengelolaan terhadap manajemen laba riil yaitu sebesar $18,6 \%$ sehingga memberikan kontribusi yang signifikan terhadap peningkatan manajemen laba riil pada perusahaan yang terdaftar dalam indeks LQ-45 di BEI Tahun 2013 2017.

\subsubsection{Pengaruh Langsung Asimetri Informas terhadap Manajemen Laba Riil pada Perusahaan Yang Terdaftar dalam Indeks LQ-45 di BEI Tahun 2013 - 2017}

Hasil penelitian menunjukkan adanya pengaruh langsung yang signifikan dari asimetri informasi terhadap manajemen laba riil pada perusahaan yang terdaftar dalam indeks LQ-45 di BEI Tahun 2013 2017. Hal ini terbukti melalui hasil pengujian hipotesis dalam persamaan analisis jalur yang menunjukkan bahwa nilai probabilitas koefisien path pengaruh asimetri informasi terhadap manajemen laba riil sebesar 0,000 lebih kecil dari taraf signifikansi 0,05. Besarnya pengaruh asimetri informasi terhadap manajemen laba riil yaitu sebesar 46,3\%. Dengan demikian, semakin besar asimetri informasi akan meningkatkan manajemen laba riil pada perusahaan yang terdaftar dalam indeks LQ-45 di BEI Tahun 2013 - 2017 dengan kemampuan menjelaskan sebesar 46,3\%.

4.2.6 Pengaruh Tidak Langsung Struktur Kepemilikan Terhadap Manajemen Laba Riil pada Perusahaan Yang Terdaftar dalam Indeks LQ-45 di BEI Tahun 2013 - 2017 Melalui Asimetri Informasi

Hasil penelitian ini menunjukkan adanya pengaruh tidak langsung yang signifikan struktur kepemilikan terhadap manajemen laba riil yang dimediasi oleh asimetri informasi. Besarnya pengaruh tidak langsung struktur kepemilikan terhadap manajemen laba riil melalui asimetri informasi yaitu sebesar $16,5 \%$. Hal ini berarti peningkatan struktur kepemilikan akan meningkatkan asimetri informasi yang pada tahap selanjutnya memberikan dampak pada peningkatan manajemen laba riil dengan kemampuan menjelaskan sebesar 16,5\%.

\subsubsection{Pengaruh Tidak Langsung Struktur Pengelolaan Terhadap Manajemen Laba Riil pada Perusahaan Yang Terdaftar dalam Indeks LQ-45 di BEI Tahun 2013 - 2017 Melalui Asimetri Informasi}

Hasil penelitian ini menunjukkan adanya pengaruh tidak langsung yang signifikan struktur pengelolaan terhadap manajemen laba riil yang dimediasi oleh asimetri informasi. Besarnya pengaruh tidak langsung struktur pengelolaan terhadap manajemen laba riil melalui asimetri informasi yaitu sebesar $21,1 \%$. Hal ini berarti peningkatan struktur pengelolaan akan meningkatkan asimetri informasi yang pada tahap selanjutnya memberikan dampak pada peningkatan manajemen laba riil dengan kemampuan menjelaskan sebesar $21,1 \%$.

\section{KESIMPULAN DAN SARAN}

\subsection{Kesimpulan}

Berdasarkan hasil penelitian dapat disimpulkan hal-hal sebagai berikut:

1. Struktur kepemilikan memiliki pengaruh langsung terhadap asimetri informasi pada perusahaan yang terdaftar dalam indeks LQ-45 di BEI Tahun 2013 2017.

2. Struktur kepemilikan tidak memiliki pengaruh langsung yang signifikan terhadap manajemen laba riil pada perusahaan yang terdaftar dalam indeks LQ-45 di BEI Tahun 2013 - 2017.

3. Struktur pengelolaan memiliki pengaruh langsung terhadap asimetri informasi pada perusahaan yang terdaftar dalam indeks LQ-45 di BEI Tahun 2013 2017.

4. Struktur pengelolaan memiliki pengaruh langsung yang signifikan terhadap manajemen laba riil pada perusahaan yang terdaftar dalam indeks LQ-45 di BEI Tahun 2013 - 2017

5. Asimetri informasi memiliki pengaruh langsung terhadap manajemen laba riil pada perusahaan yang terdaftar dalam indeks LQ-45 di BEI Tahun 2013 2017.

6. Struktur kepemilikan memiliki pengaruh tidak langsung yang signifikan terhadap manajemen laba riil yang dimediasi oleh asimetri informasi pada perusahaan yang terdaftar dalam indeks LQ-45 di BEI Tahun 2013 - 2017

7. Struktur pengelolaan memiliki pengaruh tidak langsung yang signifikan terhadap manajemen laba riil yang dimediasi oleh asimetri informasi pada perusahaan yang terdaftar dalam indeks LQ-45 di BEI Tahun 2013 - 2017 


\subsection{Keterbatasan}

Penelitian ini memiliki keterbatasan antara lain sebagai berikut:

1. Penelitian ini hanya menggunakan perusahaan yang terdaftar dalam indeks LQ-45 di Bursa Efek Indonesia yang memiliki karakteristik perusahaan yang tidak terlalu beragam terutama pada struktur kepemilikan yang didominasi oleh institusi dan sedikitnya proporsi kepemilikan manajerial.

2. Penelitian ini hanya menggunakan faktor corporate governance yang terdiri dari dua variabel struktur kepemilikan dan struktur pengelolaan yang dianggap memiliki pengaruh terhadap asimetri informasi dan praktik manajemen laba riil.

\subsection{Saran}

Berdasarkan kesimpulan hasil penelitian ini sebagaimana diuraikan di atas, maka peneliti menyumbangkan saran sebagai berikut:

1. Bagi perusahaan yang terdaftar dalam indeks LQ-45 di BEI Tahun 2013 - 2017 supaya menerapkan prinsip good governance terutama melakukan transparansi informasi keuangan tidak hanya kepada pemilik saham mayortitas, tetapi juga informasi seluas-luasnya bagi pemilik saham publik.

2. Bagi perusahaan yang terdaftar dalam indeks LQ-45 di BEI Tahun 2013 - 2017 supaya memeperbaiki tata kelola perusahaan terutama pada struktur pengelolaan dengan tujuan untuk meningkatkan pengawasan terhadap perilaku oportunistik manajeman perusahaan untuk mengurangi praktik manajemen laba riil yang dilakukan oleh manajemen perusahaan.

3. Bagi peneliti selanjutnya supaya melakukan penelitian dengan subjek penelitian yang lebih beragam misalnya dengan menggunakan seluruh perusahaan yang terdaftar di BEI.

4. Bagi peneliti selanjutnya supaya menggunakan faktor-faktor lainnya sebagai variabel yang mempengaruhi manajemen laba riil seperti kinerja keuangan, kelengkapan informasi laporan keuangan, biaya modal dan lain sebagainya.

\section{DAFTAR REFERENSI}

Ghozali, Imam. 2011, Structural Equation Modeling Metode Alternatif dengan Partial Least Square (PLS) Edisi 3. Semarang: Badan Penerbit Universitas Diponegoro.

Hengky, Latan dan Imam Ghozali.2012.Partial Least Square "Konsep, Teknik dan Aplikasi" SmartPLS 2.0 M3. Semarang: Badan Penerbit Universitas. Diponegoro.
Hari, C. Bintang. 2012. Karakteristik Dewan Komisaris dan Manajemen Laba.Majalah Ekonomi Tahun XXII, No.1.

Herawaty, Vinola. 2008. Peran Praktek Corporate Governance Sebagai. Moderating Variable dari Pengaruh Earnings Management Terhadap Nilai. Perusahaan. Jurnal Akuntansi dan Keuangan, Vol.10, No.2, 97-108.

Hussein, Ananda Sabil. 2015. Penelitian Bisnis dan Manajemen Menggunakan Partial Least Squares (PLS) dengan smartPLS 3.0. Modul Ajar. Jurusan Manajemen Fakultas Ekonomi Dan Bisnis Universitas Brawijaya.

Iraya, Cyrus, Mirie Mwangi dan Gilbert W. Muchoki. 2015. The Effect of Corporate Governance Practices on Earnings Management of Companies Listed At the Nairobi Securities Exchange. European Scientific Journal January 2015 edition vol.11, No.1 ISSN: 1857 - 7881 (Print) e - ISSN 1857- 7431

Jensen, M., dan Meckling, W. 1976. Theory of The firm: Managerial Behavior, Agency Costs and Ownership Structure. Journal of Financial Economics, 3: 305-360.

Komite Nasional Kebijakan Governance. 2006. Pedoman Good Corporate Governance Indonesia.Jakarta.

Kusumawati, Eny, Shinta Permata Sari, dan Rina Trisnawati. 2013. Pengaruh Asimetri Informasi dan Mekanisme Corporate Governance terhadap Praktik Earnings Management (Kajian Perbandingan Perusahaan yang Terdaftar dalam Indeks Syariah dan Indeks Konvensional Bursa Efek Indonesia). Proceeding Seminar Nasonal dan Call For Papers Sancall ISBN: 978-979-636-1472, Maret 2013.

Kusumawati, Eny, Rina Trisnawati, dan Ahmad Mardalis. 2015. Pengaruh Corporate Governance Terhadap Manajemen Laba Riil. The 2nd University Research Coloquium.,Hal: 339-350, ISSN: 2407-9189.

Lisa, O. 2012. Asimetri Informasi dan Manajemen Laba: Suatu Tinjauan dalam Hubungan Keagenan. Jurnal WIGA Vol. 2 No. 1, Maret 2012 ISSN NO 2088-0944

Nurlis. 2016. The Effect of Mechanism of Good Corporate Governance and Investment Opportunity Set on the Earning Management: Study On Property and Real Estate Companies Are Listed In Indonesia Stock Exchange. European Journal of Business and Management ISSN 2222 - 
1905 (Paper) ISSN 2222-2839 (Online) Vol.8, No.2, 2016www.iiste.org.

Panji, Aditya. 2015. Terbukti Palsukan Laporan Keuangan, CEO Toshiba Minta Maaf. Diakses dari https://www.cnnindonesia.com/ Tanggal 5 April 2018.

Pratiwi, A., Nurkholis, dan A. Ghofar. 2015. Pengaruh Corporate Governance dan Struktur Kepemilikan terhadap Asimetri Informasi. JAAI Volume 19 Nomor 2, Desember 2015: 99 111.Https://doi.org/10.20885/jaai.vol19.iss2.art2

Riwayati, Hedwigis Esti, Markonah, dan Muldjanto Siladjaja. 2016. Implementation of Corporate Governance Influence to Earnings Management. Procedia - Social and Behavioral Sciences 219 (2016) $632-638$.

Sun, Jerry, George Lan, and Guoping Liu. 2014. Independent Audit Committee Characteristics and Real Earnings Management. Managerial Auditing Journal, Vol. 29, No.2.

Susanto, Yulius Kurnia dan Arya Pradipta. 2016. Corporate Governance and Real Earnings Management.International Journal of Business, Economics and Law, Vol. 9, Issue 1 (Apr.)2016 ISSN 2289-1552.

Susanto, Yulius Kurnia. 2016. The Effect of Audit Committees and Corporate Governance on Earnings Management: Evidence from Indonesia Manufacturing Industry. International Journal of Business, Economics and Law, Vol. 10, Issue 1 (Aug.) 2016 ISSN 2289-1552.

Swastika, Dwi Lusi Tyasing. 2013. Corporate Governance, Firm Size, and Earning Management: Evidence in Indonesia Stock Exchange.IOSR Journal of Business and Management (IOSR-JBM) e-ISSN: 2278-487X, pISSN: 2319-7668. Volume 10, Issue 4 (May. - Jun. 2013), PP 77-82 www.iosrjournals.org.

Uwuigbe, Uwalomwa, Daramola Sunday Peter dan Anjolaoluwa Oyeniyi. 2014. The effects of corporate governance mechanisms on earnings management of listed firms in Nigeria. Accounting and Management Information Systems Vol. 13, No. 1, pp. 159-174, 2014

Wicaksana, KAB, N W Yuniasih, dan L N C Handayani. 2017. Board diversity and earning management in companies listed in Indonesian stock exchange. International Journal of Scientific and Research Publications, Volume 7, Issue 12, December 2017 ISSN 2250-3153

Wiryandi, A. dan Sebrina Nurzi. 2013. Pengaruh Asimetri Informasi, Kualitas Audit, dan Struktur
Kepemilikan terhadap Manajemen Laba. Wahana Riset Akuntansi Vol. 1, No. 2, Oktober 2013.

Yang, W. S., Loo, S. C., and Shamser. 2009. The Effect of Board Structure and Institutional Ownership Structure on Earnings Management. International Journal of Economics and Management, Vol.3, No.2: 332-353, ISSN: 1823-836X. 